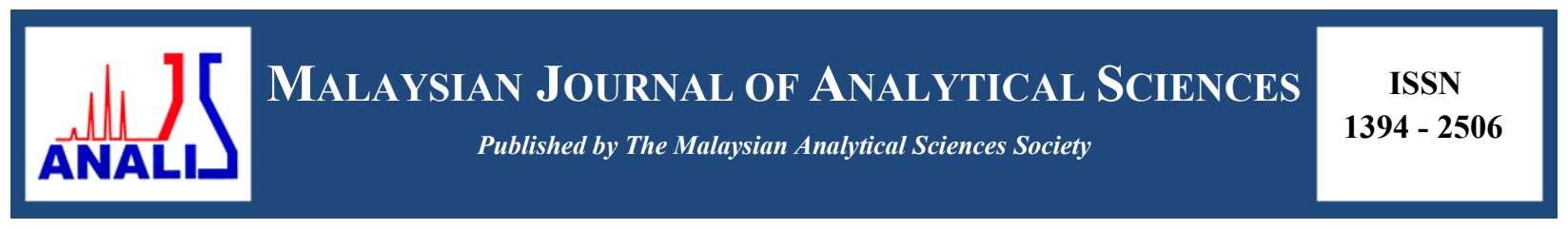

\title{
FABRICATION OF PES/MnO MIXED MATRIX MEMBRANES FOR CADMIUM REMOVAL
}

\author{
(Pembuatan PES/MnO Membran Campuran Matrik dalam Penyingkiran Kadmium) \\ Soon Onn Lai ${ }^{1}$, Kok Chung Chong ${ }^{1}$, Zhi Wei Kerk ${ }^{1}$, Boon Seng Ooi ${ }^{2}$, Woei Jye Lau ${ }^{3}$ \\ ${ }^{1}$ Lee Kong Chian Faculty of Engineering and Science, \\ Universiti Tunku Abdul Rahman, Jalan Sungai Long, Bandar Sungai Long, 43300 Kajang, Malaysia \\ ${ }^{2}$ School of Chemical Engineering, Engineering Campus, \\ University Sains Malaysia, Seri Ampangan, 14300 Nibong Tebal, Pulau Pinang, Malaysia. \\ ${ }^{3}$ Advanced Membrane Technology Research Centre (AMTEC), \\ Universiti Teknologi Malaysia, 81310 Skudai, Johor, Malaysia \\ *Corresponding author: chobs@usm.my
}

Received: 26 August 2016; Accepted: 8 January 2017

\begin{abstract}
With increasing industrial activities around the globe, water source had been severely polluted by various heavy metal substances that lead to adverse effect not only to the environment but also to human being. The content of heavy metal in wastewater especially cadmium was increasing in the recent years and can be attributed to the strong demand of cadmium in the battery and electroplating industry. In this study, the potential of novel nanocomposite mixed matrix membrane incorporated with manganese oxide $\left(\mathrm{MnO}_{2}\right)$ nanoparticle for cadmium removal was investigated. The membranes were fabricated using polyethersulfone (PES) by phase inversion technique with different manganese oxide nanoparticle loading. Prior to performance evaluation, the membranes were characterized by their structural morphology, surface chemistry and cadmium adsorption capability. The results suggested that PES membrane incorporated with 2.0 ratio of $\mathrm{MnO}_{2} / \mathrm{PES}$ exhibited the best result in both cadmium adsorption $(51.7 \mathrm{mg} / \mathrm{g})$ and water permeability $\left(1462 \mathrm{~L} / \mathrm{m}^{2} . h . b a r\right)$. This indicated the prospect of this membrane to be applied in wastewater treatment industry.
\end{abstract}

Keywords: mixed matrix membrane, polyethersulfone, cadmium, wastewater

\section{Abstrak}

Sumber air di seluruh dunia telah teruk tercemar dengan pelbagai bahan logam berat yang akan memberi kesan buruk kepada alam sekitar dan manusia. Pencemaran air ini adalah akibat daripada aktiviti-aktiviti perindustrian yang semakin pesat di dunia kita. Kandungan logam berat dalam air sisa terutamanya kadmium semakin meningkat dalam beberapa tahun ini disebabkan oleh permintaan kadmium yang tinggi terutamanya dalam industri bateri dan elektropenyaduran. Dalam kajian ini, potensi membran campuran matrik yang baharu dengan mangan oksida $\left(\mathrm{MnO}_{2}\right)$ dikajikan dalam sistem turas aliran lintang untuk penyingkiran kadmium. Membran ini dibuat daripada polietersulfona (PES) dengan teknik fasa berbalik dengan pelbagai berat zarah nano mangan oksida. Sebelum kajian dijalankan, membran dicirikan dengan kajian struktur dan permukaan morfologi, keliangan, sudut kenalan permukaan, kajian pembenaman $\mathrm{MnO}_{2}$ dan kajian penjerapan kadmium. Hasil kerja kajian ini mencadangkan bahawa membran PES dengan nisbah $2.0 \mathrm{MnO}_{2}$ menunjukkan keputusan yang memberangsangkan dalam penjerapan kadmium $(51.7 \mathrm{mg} / \mathrm{g})$ dan fluks air tulen yang paling tinggi $\left(1,462 \mathrm{~L} / \mathrm{m}^{2} . h . b a r\right)$. Keputusan kajian ini telah menunjukkan membran mempunyai potensi yang besar digunakan dalam industri rawatan air sisa.

Kata kunci: membran matriks campuran, polietersulfon, kadmium, air sisa 


\section{Introduction}

Since the industrial revolution in the human history, the environmental pollution by heavy metals has become more severe, leading to the catastrophic environmental and health problems. Cadmium (Cd) is a commonly used heavy metal in the industry, particularly in the battery, electroplating and pigment [1]. Nevertheless, $\mathrm{Cd}$ is a carcinogen to living organisms, where the presence of it will pose threat to the aquatic system and human health. Owing to strong industrial growth and increasing demand of $\mathrm{Cd}$ around the world, the wastewater containing $\mathrm{Cd}$ had increased drastically in the recent years [2].

Many wastewater treatment technologies had been developed for heavy metal removal. These include precipitation, ion exchange and solvent extraction. Although these methods are widely used in the industrial application, they possess disadvantages such as high capital cost, discharges of toxics solvent, disposal of sludge, and etc. [3]. One of the alternative methods to overcome these issues is membrane technology.

Membrane technology had been developed rapidly in the past two decades due to the advances in the membrane fabrication and characterization techniques. Several membrane separation techniques had been used in the seawater desalination and wastewater treatment, namely, reverse osmosis (RO), nanofiltration (NF) and ultrafiltration (UF) $[4,5]$. Despite the successful application of membrane technology in the wastewater industry, the membrane performance as a function of filtration time is still a main concern as membrane is prone to fouling, especially in the treatment of wastewater containing heavy metals [6]. In this work, the potential of novel mixed matrix membrane embedded with manganese oxide $\left(\mathrm{MnO}_{2}\right)$ nanoparticles was evaluated for Cd removal. The membrane fabrication and characterization techniques, adsorption behavior and separation efficiency were investigated by performing static adsorption and cross flow filtration experiment under various experimental conditions.

\section{Materials}

\section{Materials and Methods}

The main polymeric material used for the membrane fabrication was polyethersulfone (Radel A300 PES) with a molecular weight of 58,000 g/mol purchased from Amoco Chemicals. Polyvinylpyrrolidone (PVP) and Nmethylpyrrolidinone (NMP) obtained from Merck were used as additives and solvent, respectively. Ethanol and potassium permanganate were supplied by KLH Chemicals and used for nanoparticle synthesis. Cadmium chloride purchased from R \& M Chemicals was used to prepare feed solution.

\section{Synthesis of manganese oxide particles}

The synthesis method adopted in this study was similar to the literature reported by Subramanian et al. [7]. Potassium permanganate was first dissolved in distilled water followed by the addition of ethanol. The mixture was stirred until brownish black precipitate of manganese oxide was formed. The precipitate was filtered by Whitman filter paper and cleaned with distilled water to remove the unwanted impurities. Subsequently, the precipitate was dried in a vacuum oven at $60{ }^{\circ} \mathrm{C}$ for 24 hours to remove the moisture content before use.

\section{Membrane preparation}

The membrane fabrication technique employed in this study was phase inversion technique which has been discussed elsewhere in details [8]. A pre-determined amount of PES and additive $\left(\mathrm{MnO}_{2}\right.$ and PVP) were weighed and added to NMP solvent. The solution was stirred for 4 hours by magnetic stirrer followed by sonication at $60{ }^{\circ} \mathrm{C}$ for 24 hours to produce homogenous dope solution. The viscosity of the dope solution was recorded by digital viscometer (98965-40, Cole-Parmer) to investigate the effect of the ratio of $\mathrm{MnO}_{2}$ and PES.

In the flat sheet membrane fabrication, the dope solution was cast evenly onto a flat glass plate. A casting glass rod was used to cast the solution into a film with a thickness of $230-250 \mu \mathrm{m}$. The casted film was then immersed into distilled water at room temperature to induce phase inversion. The formed membrane was immersed in water for 3 days in order to removal residual trace of solvent. Finally, the membrane was dried in a vacuum oven at $60{ }^{\circ} \mathrm{C}$ for 24 hours to completely remove the moisture content. Table 1 lists the composition of dope solution used in this study for membrane fabrication. 
Table 1. Composition of dope solution

\begin{tabular}{lcccccc}
\hline Membrane & $\begin{array}{c}\mathbf{M n O}_{2} / \text { PES } \\
\text { Ratio }\end{array}$ & $\begin{array}{c}\text { PES } \\
\text { (wt.\%) }\end{array}$ & $\begin{array}{c}\text { PVP } \\
\text { (wt.\%) }\end{array}$ & $\begin{array}{c}\text { NMP } \\
\text { (wt.\%) }\end{array}$ & $\begin{array}{c}\mathbf{M n O}_{2} \\
(\mathbf{w t . \% )}\end{array}$ & $\begin{array}{c}\text { Viscosity } \\
\text { (Cp) }\end{array}$ \\
\hline $\mathrm{PES}$ & 0 & 15.00 & 1.50 & 83.50 & - & 200 \\
$\mathrm{MnO}_{2} /$ PES-0.5 & 0.5 & 13.95 & 1.40 & 77.67 & 6.98 & 1,800 \\
$\mathrm{MnO}_{2} /$ PES-1.0 & 1.0 & 13.04 & 1.30 & 72.60 & 13.04 & 2,000 \\
$\mathrm{MnO}_{2} /$ PES-1.5 & 1.5 & 12.24 & 1.22 & 68.18 & 18.36 & 9,450 \\
$\mathrm{MnO}_{2} /$ PES-2.0 & 2.0 & 11.54 & 1.15 & 64.23 & 23.08 & 12,450 \\
$\mathrm{MnO}_{2} /$ PES-2.2 & 2.2 & 11.28 & 1.13 & 62.78 & 24.81 & 13,250 \\
\hline
\end{tabular}

\section{Characterization}

The structure of the $\mathrm{MnO}_{2}$ was identified by transmission electron microscopy (TEM). The $\mathrm{MnO}_{2}$ sample was first reduced for $30 \mathrm{~min}$ by inducing hydrogen to remove any carbon deposit, and then carefully transferred to a porous carbon film supported on a metal grid at scale bar of 20 to $50 \mathrm{~nm}$. The sample was then examined with an accelerating voltage at $400 \mathrm{KeV}$ to obtain the electron micrographs.

Fourier transform infrared-attenuated total reflectance (FTIR-ATR) (Perkin Elmer) was used to investigate the functional group of $\mathrm{MnO}_{2}$ before and after the cadmium adsorption test. Additionally, the functional groups of $\mathrm{MnO}_{2}$ particles in the PES membranes were also identified by FTIR-ATR.

The membrane surface and cross sectional morphologies were examined using scanning electron microscope (SEM) (Hitachi TM3000). The samples were cryogenically fractured liquid nitrogen into a small strip. The membranes were then coated with a thin layer of platinum by sputter machine before SEM analysis.

Both membrane surface roughness and pore size of the flat sheet membranes were structurally characterized using atomic force microscopy (AFM) (Seiko SPA-300HV). The membrane samples were first washed using ethanol to remove any trace residual. The samples were cut into square pieces with area of approximately $1.0 \mathrm{~cm}^{2}$ and attached to the sample holder in the scanner tube. The AFM images were obtained with tapping mode with a scanning size of $5 \mu \mathrm{m} \times 5 \mu \mathrm{m}$.

The contact angle of the flat sheet membrane was measured by sessile drop technique using contact angle goniometer (DataPhysics, OCA15Plus). Distilled water droplet was placed on 10 to 20 regions on the membrane surface and average contact angle was reported.

Membrane porosity was calculated by the gravitational method as explained in the literature [9]. The weight of the membrane samples were first weighted as dry weight and then immersed into water for 24 hours. The weight of the wetter membrane was measured as wet weight and the porosity $\left(P_{r}\right)$ was determined using Equation 1.

$$
P_{r}=\frac{W_{w}-W_{d}}{d_{w} \times s \times l}
$$

where $W_{w}$ is the weight of wet membrane $(\mathrm{g}), W_{d}$ is the weight of dry membrane $(\mathrm{g}), s$ is the surface area of membrane $\left(\mathrm{cm}^{2}\right), l$ is the thickness of wet membrane $(\mathrm{cm})$ and $d_{w}$ is the density of water at room temperature.

\section{Experimental work}

The adsorption test of cadmium using the fabricated membrane was studied using batch adsorption technique. The Cd solution was prepared by dissolving cadmium chloride $\left(\mathrm{CdCl}_{2}\right)$ in distilled water. The batch adsorption was carried out in a $15 \mathrm{~mL}$ sample tube with $10 \mathrm{~mL}$ of Cd solution with a concentration of $30 \mathrm{ppm}$ and membrane with mass of $0.01 \mathrm{~g}$, and $\mathrm{pH}$ value remained as constant at 9. The sample tube was placed in incubation shaker at 250 $\mathrm{rpm}, 25{ }^{\circ} \mathrm{C}$ for 48 hours. Additionally, the effect of $\mathrm{pH}$ value on the $\mathrm{Cd}$ adsorption was investigated by mixing the 
membrane with $10 \mathrm{~mL}$ of $100 \mathrm{ppm} \mathrm{Cd}$ solution at different $\mathrm{pH}$ values. The concentration of $\mathrm{Cd}$ residual was analyzed using inductively coupled plasma-optical emission spectrometry (ICP-OES). The analysis was repeated three times to yield average result. The equilibrium adsorption capacity $\left(q_{e}\right)$ of the membrane was determined using Equation 2 [10].

$$
q_{e}=\frac{\left(C_{i}-C_{e}\right) V}{M_{m}}
$$

where $c_{i}(\mathrm{mg} / \mathrm{g})$ is the initial Cd solution concentration, $c_{e}(\mathrm{mg} / \mathrm{g})$ is the equilibrium Cd solution concentration, $v$ is the volume of Cd solution $(l)$ and $M_{m}$ is the mass of the dry membrane which is added into the solution $(\mathrm{g})$.

The Cd removal was also conducted by the cross flow filtration system as illustrated in Figure 1. Flat sheet membrane with an area of $14.5 \mathrm{~cm}^{2}$ was installed in the membrane module. The feed stream consisting of $\mathrm{Cd}$ solution with a concentration of $100 \mathrm{ppm}$ was pumped into the membrane module at 0.1 bar. The quality of permeate was determined at every $30 \mathrm{~min}$ interval by ICP-OES. The pure water flux is then determined by Equation $3[10]$.

$$
J_{w}=\frac{Q}{A \Delta t \Delta p}
$$

where $J_{w}$ is pure water flux $\left(1 / \mathrm{m}^{2} . h\right), Q$ is the volume of permeate (l), $A$ is the effective membrane area $\left(\mathrm{m}^{2}\right), \Delta t$ is the sampling time (h) and $\Delta p$ is the transmembrane pressure difference.

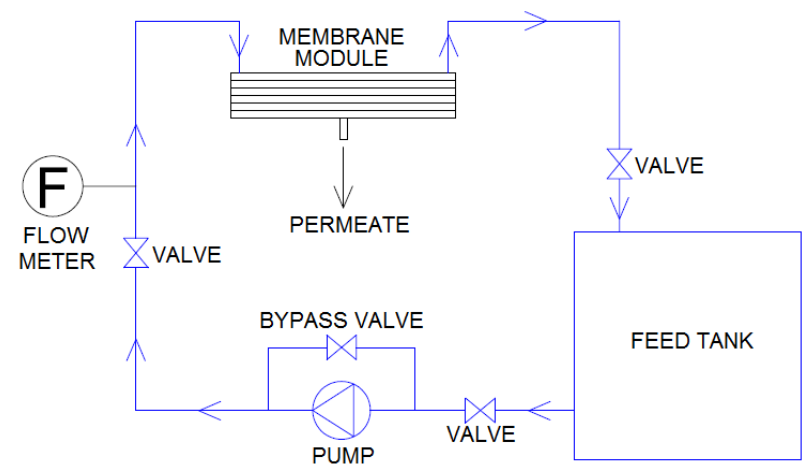

Figure 1. Schematic diagram of cross flow filtration system

\section{Results and Discussion \\ Characterization of $\mathrm{MnO}_{2}$ nanoparticles and PES/MnO}

Figure 2 shows the images of six different membranes used in the experiment. It was observed that the color of membrane turned brownish when $\mathrm{MnO}_{2}$ was added to PES. The color became darker with higher dosage of $\mathrm{MnO}_{2}$. The results were consistent with the original colour of $\mathrm{MnO}_{2}$.

Figure 3 shows the TEM images of the synthesized $\mathrm{MnO}_{2}$. The $\mathrm{MnO}_{2}$ structure appeared to be rod-like structure with a dimension of $125 \pm 30 \mathrm{~nm}$. Such structure was achieved when the product of $\mathrm{MnO}_{2}$ was formed as a result of addition of ethanol to aqueous solution of potassium permanganate $\left(\mathrm{KMnO}_{4}\right)$. 


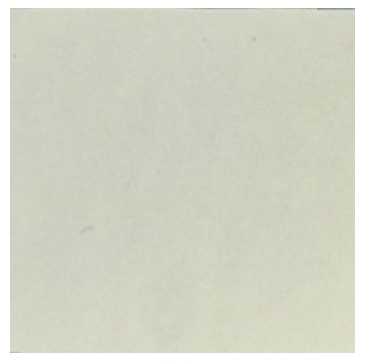

(a)

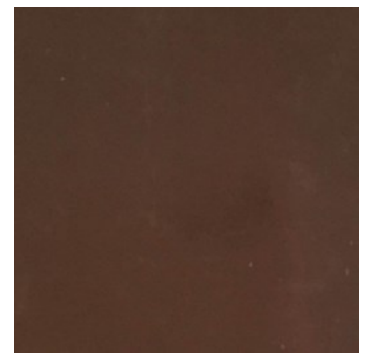

(d)

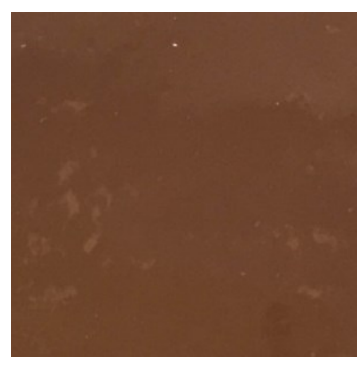

(b)

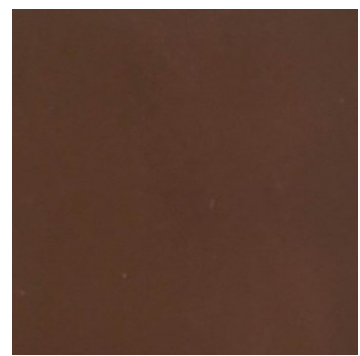

(e)

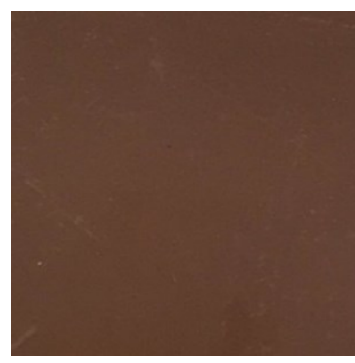

(c)

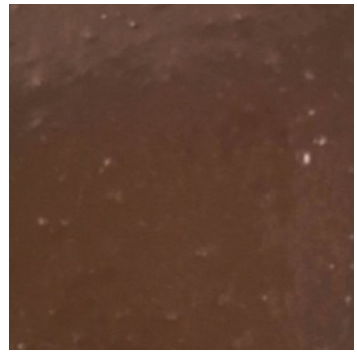

(f)

Figure 2. Images of six different membranes used (a) PES, (b) $\mathrm{MnO}_{2} / \mathrm{PES}-0.5$, (c) $\mathrm{MnO}_{2} / \mathrm{PES}-1.0$, (d) $\mathrm{MnO}_{2} / \mathrm{PES}-$ 1.5 , (e) $\mathrm{MnO}_{2} / \mathrm{PES}-2.0$ and (f) $\mathrm{MnO}_{2} / \mathrm{PES}-2.2$

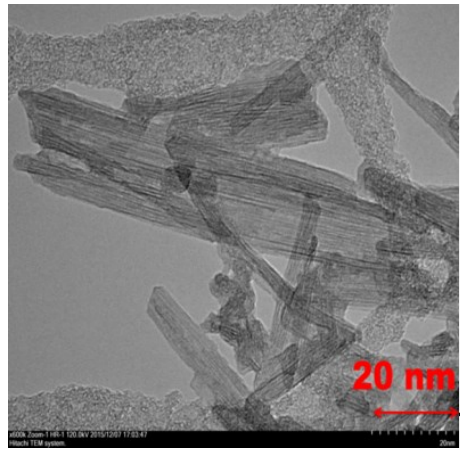

(a)

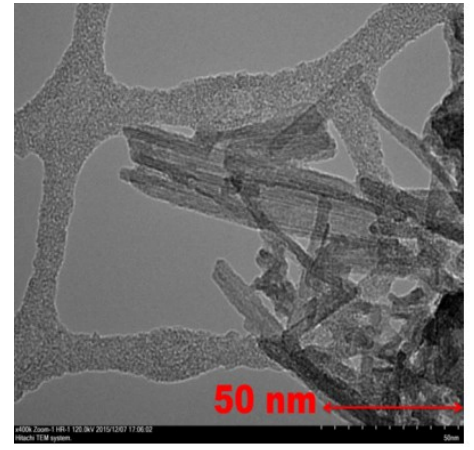

(b)

Figure 3. TEM images of manufactured $\mathrm{MnO}_{2}$ at different scale bars, (a) $20 \mathrm{~nm}$ and (b) $50 \mathrm{~nm}$

Figure 4 depicts the FTIR spectra of $\mathrm{MnO}_{2}$ particles and the membrane embedded with and without $\mathrm{MnO}_{2}$. It is found that a sequence of adsorption bands for the $\mathrm{MnO}_{2}$ was appeared at $3394.8,1542.5$ and $1412.2 \mathrm{~cm}^{-1}$. Strong adsorption peak observed at $3394.8 \mathrm{~cm}^{-1}$ was assigned to -OH stretching vibration because large amount of hydroxyl groups presented in $\mathrm{MnO}_{2}$. The band at region of $1542.5 \mathrm{~cm}^{-1}$ might be attributed to asymmetric N-O stretching vibration. On the other hand, the band at region of $1412.23 \mathrm{~cm}^{-1}$ might be resulted by $\mathrm{C}-\mathrm{C}$ stretching vibration. 


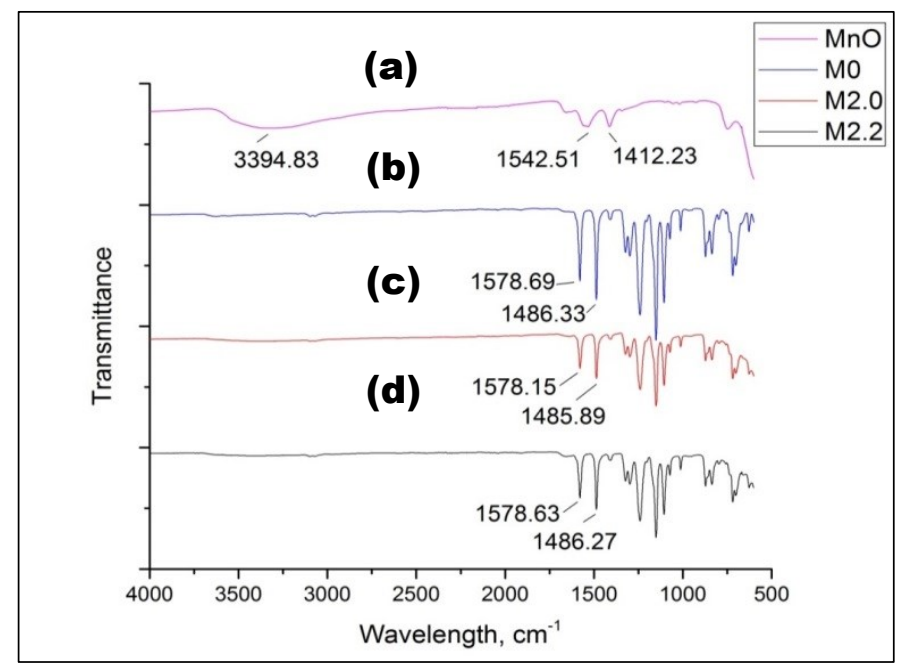

Figure 4. FTIR spectrums of (a) $\mathrm{MnO}_{2}$ particles, (b) PES, (c) $\mathrm{MnO}_{2} / \mathrm{PES}-2.0$ and (d) $\mathrm{MnO}_{2} / \mathrm{PES}-2.2$

Table 2 summarizes the contact angle when water droplet placed onto the surface of six different membranes. It could be observed that the contact angle decreased significantly from $63.73^{\circ}$ for the neat membrane to $18.13^{\circ}$ for the $\mathrm{MnO}_{2} / \mathrm{PES}-2.2$ membrane. This indicated significant improvement in membrane surface hydrophilicity. Such improvement resulted from embedding $\mathrm{MnO}_{2}$ particles in the PES membrane was most probably due to the presence of large amount of hydroxyl groups in $\mathrm{MnO}_{2}$, which could be proved by FTIR result. A membrane with improved surface hydrophilicity generally would ameliorate membrane water permeability as shown in Table 2 . It could also be noticed that the overall porosity values of all membranes were high $(76-94.8 \%)$ (Table 2). This could be caused by low concentration of polymer used as well as addition of PVP (which acted as pore forming agent) in the casting solution. Moreover, the porosity appeared to increase from $76.81 \%$ in neat PES membrane to $94.81 \%$ in the $\mathrm{MnO}_{2} / \mathrm{PES}-2.2$ membrane. This was due to the addition of $\mathrm{MnO}_{2}$, which was super-hydrophilic in nature as evidenced by the results of FTIR and contact angle.

Table 2. Pure water permeability, contact angle and overall porosity of various membranes

\begin{tabular}{lccc}
\hline Membrane & $\begin{array}{c}\text { PWF } \\
\left(\mathbf{L} / \mathbf{m}^{2} \mathbf{h}\right)\end{array}$ & $\begin{array}{c}\text { Contact Angle } \\
(\mathbf{(})\end{array}$ & $\begin{array}{c}\text { Overall Porosity } \\
\mathbf{( \% )}\end{array}$ \\
\hline $\mathrm{PES}$ & $22.74( \pm 0.39)$ & $63.73( \pm 2.96)$ & $76.81( \pm 0.65)$ \\
$\mathrm{MnO}_{2} /$ PES-0.5 & $234.93( \pm 1.68)$ & $46.89( \pm 4.45)$ & $77.11( \pm-0.13)$ \\
$\mathrm{MnO}_{2} /$ PES-1.0 & $248.84( \pm 1.56)$ & $37.68( \pm 6.18)$ & $77.73( \pm 0.21)$ \\
$\mathrm{MnO}_{2} /$ PES-1.5 & $508.77( \pm 1.68)$ & $32.94( \pm 8.52)$ & $81.31( \pm 0.44)$ \\
$\mathrm{MnO}_{2} /$ PES-2.0 & $1461.99( \pm 3.93)$ & $20.82( \pm 4.52)$ & $85.89( \pm 0.36)$ \\
$\mathrm{MnO}_{2} /$ PES-2.2 & $1288.36( \pm 12.33)$ & $18.13( \pm 7.57)$ & $94.81( \pm 0.28)$ \\
\hline
\end{tabular}

Figure 5 shows the AFM surface images of all the membrane samples provided in atomic-level resolution. $R a$ value is known as roughness value. It increased drastically from $17.34 \mathrm{~nm}$ in the neat membrane (M0) to $>58 \mathrm{~nm}$ in the $\mathrm{MnO}_{2} / \mathrm{PES}-2.0$ membrane when the weight ratio of $\mathrm{MnO}_{2} / \mathrm{PES}$ was increased from zero to 2.0. This could be resulted by the distribution of $\mathrm{MnO}_{2}$ embedded in the membranes. A membrane with higher roughness value indicates better filtration performance. Hence, the M2.0 membrane was shown to have the best filtration performance compared with the M2.2 membrane. 


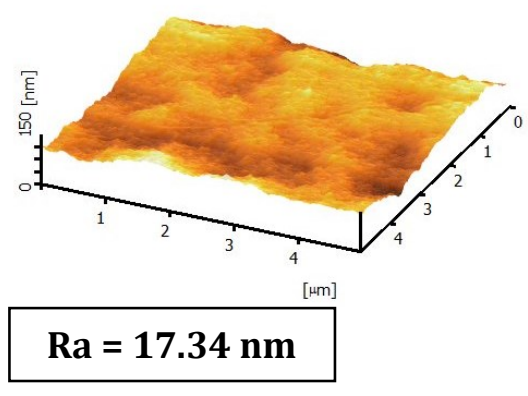

(a)

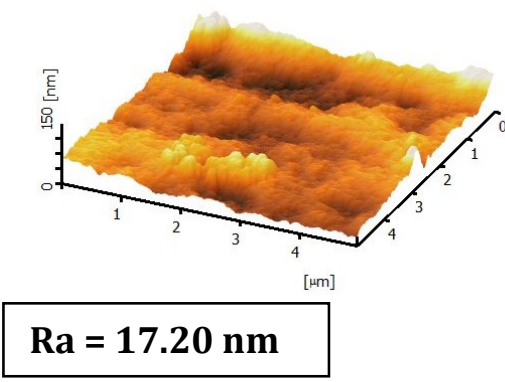

(c)

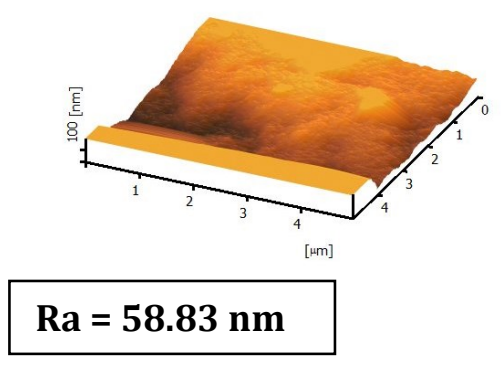

(e)

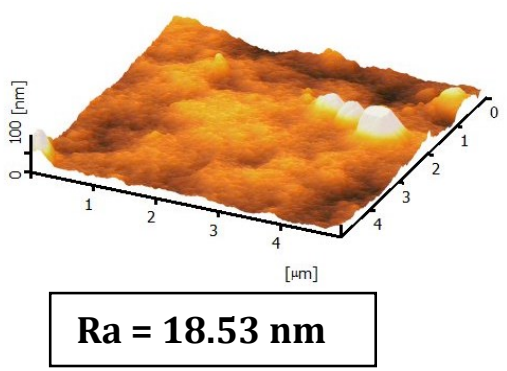

(b)

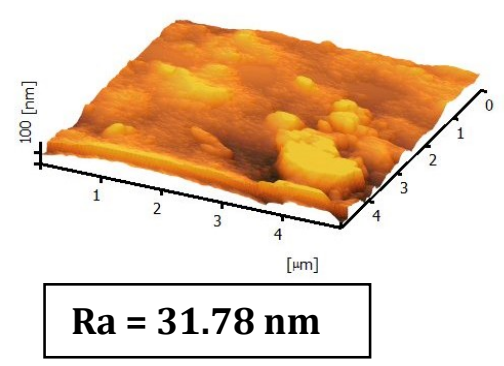

(d)

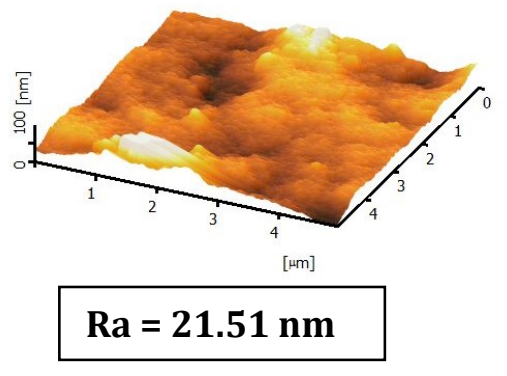

(f)

Figure 5. AFM images of various membranes with different $\mathrm{MnO}_{2} / \mathrm{PES}$ ratios, (a) PES, (b) $\mathrm{MnO}_{2} / \mathrm{PES}-0.5$, (c) $\mathrm{MnO}_{2} /$ PES-1.0,(d) $\mathrm{MnO}_{2} / \mathrm{PES}-1.5$, (e) $\mathrm{MnO}_{2} / \mathrm{PES}-2.0$ and (f) $\mathrm{MnO}_{2} / \mathrm{PES}-2.2$

\section{Cadmium adsorption studies: Effect of adsorbent dosage and initial concentration (isotherm analysis)}

Both the effects of adsorbent dosage and initial concentration were studied at $25{ }^{\circ} \mathrm{C}$ and $\mathrm{pH}=9$ by differing the $\mathrm{Cd}$ initial concentration of $10,30,50$ and $100 \mathrm{ppm}$ for various membranes with different $\mathrm{PES} / \mathrm{MnO}_{2}$ ratios. Neat membrane was not tested for this experiment because it had no adsorption capacity of $\mathrm{Cd}$ due to the absence of $\mathrm{MnO}_{2}$ particles. Figure 6 shows that when the $\mathrm{MnO}_{2} / \mathrm{PES}$ ratio increased, the Cd adsorption capacity increased accordingly. The maximum $\mathrm{Cd}$ adsorption capacity for $\mathrm{MnO}_{2} / \mathrm{PES}-0.5, \mathrm{MnO}_{2} / \mathrm{PES}-1.0, \mathrm{MnO}_{2} / \mathrm{PES}-1.5, \mathrm{MnO}_{2} / \mathrm{PES}-$ 2.0 and $\mathrm{MnO}_{2} / \mathrm{PES}-2.2$ were found to be $31.63,35.29,45.89,51.71$ and $49.82 \mathrm{mg} / \mathrm{g}$, respectively. The enhancing adsorption capacity of prepared membranes was clearly attributed to the increasing dosage of $\mathrm{MnO}_{2}$ adsorbents for $\mathrm{Cd}$ adsorption. In addition, the positive relationship between initial $\mathrm{Cd}$ concentration and $\mathrm{Cd}$ adsorption capacity was also obviously observed in Figure 6. 


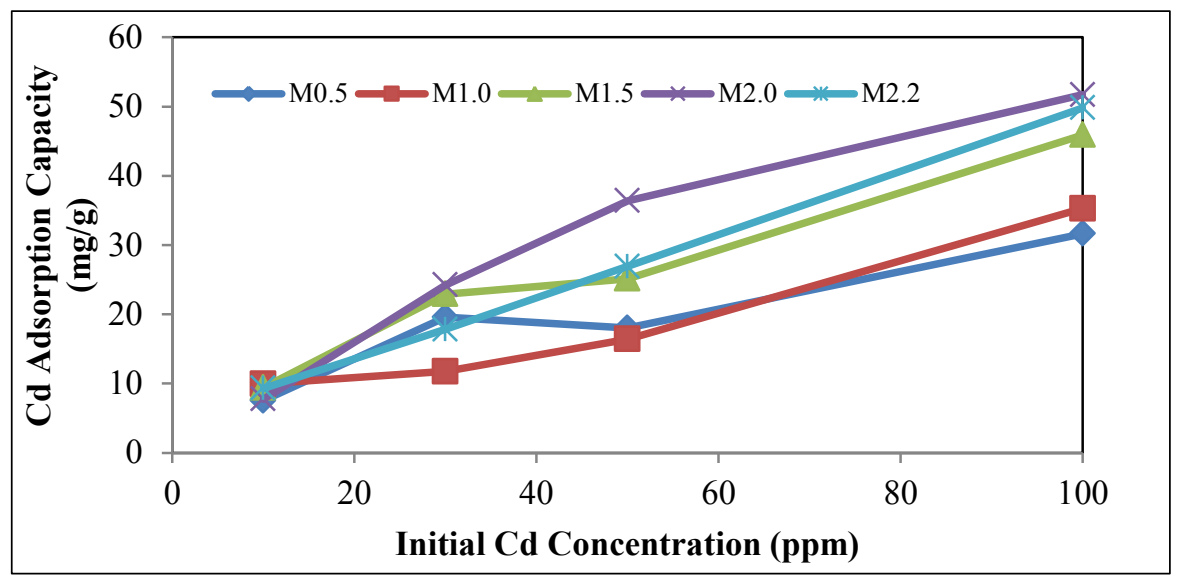

Figure 6. Adsorption isotherm of $\mathrm{Cd}$ using membranes with different $\mathrm{MnO}_{2} / \mathrm{PES}$ ratios. (Operating Conditions: $\mathrm{pH}=9$, membrane dose $=1 \mathrm{~g} / \mathrm{L}$, temperature $=25^{\circ} \mathrm{C}$, contact time $=48$ hours $)$

\section{Effect of pH}

The $\mathrm{pH}$ value is deemed to be a pivotal parameter in controlling $\mathrm{Cd}$ removal efficiency because of the strong aggressive bond between hydrogen ions and heavy metal ions in allocation of sites for adsorption. Figure 7 shows

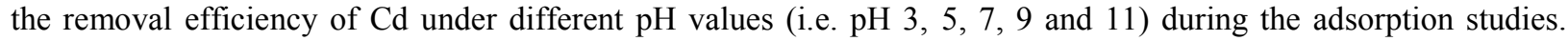
From the experiment, $\mathrm{MnO}_{2} / \mathrm{PES}-2.0$ membrane was chosen to be used because of its highest adsorption capacity among other membranes. As can be seen, better Cd removal efficiency was found to be in alkaline solution. The optimum Cd removal was observed between $\mathrm{pH} 9$ to $\mathrm{pH} 11$ for the $\mathrm{MnO}_{2} / \mathrm{PES}-2.0$ membrane attributed to the increase in the electrostatic attraction between the positively charge $\mathrm{Cd}^{2+}$ ions and the negative charged binding sites of the functional group present on the cell surface which is similar to the reported by Al-Homaidan et al. and Adhiya et al $[11,12]$.

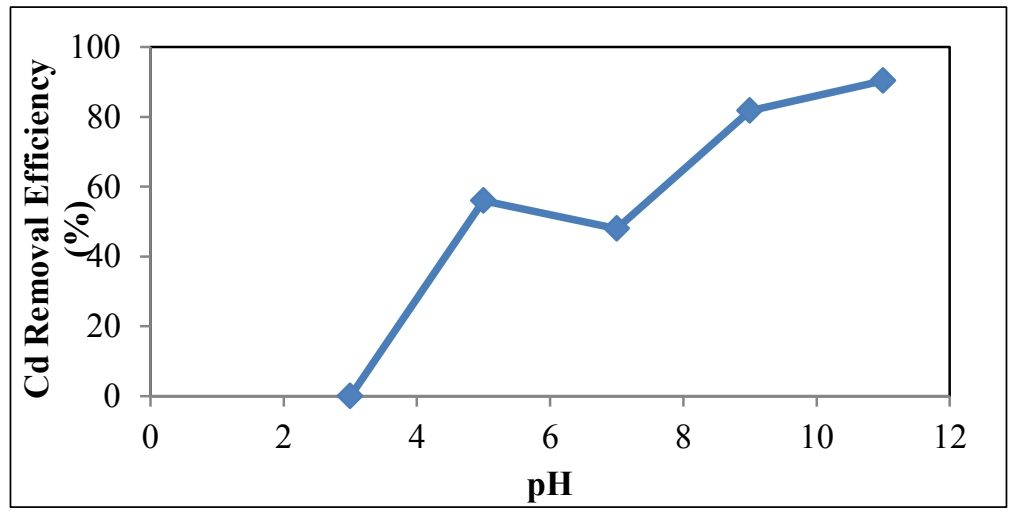

Figure 7. Effect of initial $\mathrm{pH}$ value on $\mathrm{Cd}$ removal by $\mathrm{MnO}_{2} / \mathrm{PES}-2.0$ (Operating Conditions: initial $\mathrm{Cd}$ concentration $=30 \mathrm{mg} / \mathrm{L}$, membrane dose $=1 \mathrm{~g} / \mathrm{L}$, temperature $=25^{\circ} \mathrm{C}$, contact time $=48$ hours)

\section{Effect of contact time}

Effect of contact time $(5,10,20,30,60,120,240,360,480$ and $720 \mathrm{~min})$ was investigated for the $\mathrm{MnO}_{2} / \mathrm{PES}-2.0$ membrane at initial $\mathrm{Cd}$ concentration of $30 \mathrm{ppm}$. Figure 8 shows that $\mathrm{Cd}$ was more rapidly removed at the starting, 
while the removal rate slowed down as the time passed. The higher rate of Cd removal initially might be due to larger surface area of the membrane embedded with $\mathrm{MnO}_{2}$ for $\mathrm{Cd}$ adsorption. As time passed, the availability of surface area would become smaller, and hence the rate of $\mathrm{Cd}$ removal slowed down. The adsorption equilibrium was reached after $480 \mathrm{~min}$.

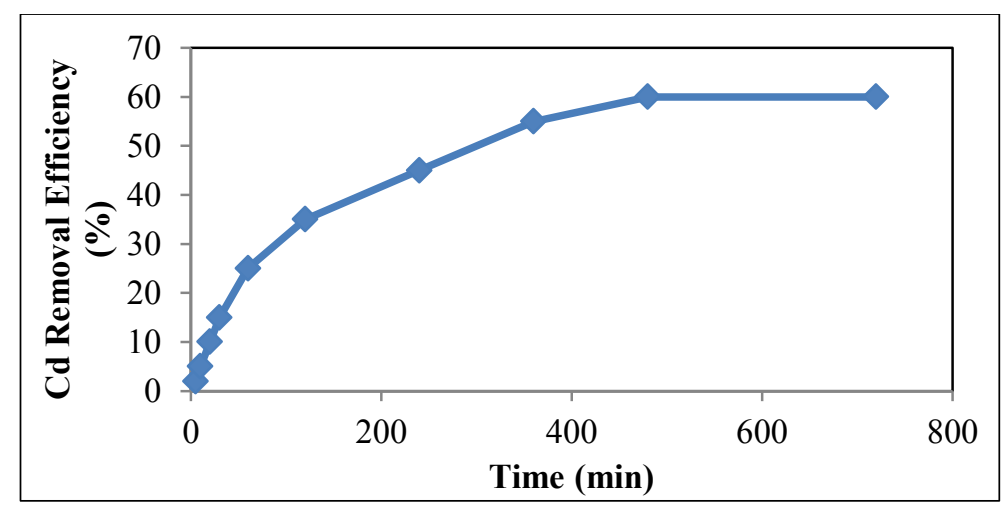

Figure 8. Effect of contact time on Cd removal by $\mathrm{MnO}_{2} / \mathrm{PES}-2.0$ (Operating Conditions: initial Cd concentration $=30 \mathrm{mg} / \mathrm{L}$, membrane dose $=1 \mathrm{~g} / \mathrm{L}$, temperature $=25^{\circ} \mathrm{C}, \mathrm{pH}=9$ )

\section{Continuous filtration}

The performance of optimum membrane, which was PES/ $\mathrm{MnO}_{2}-2.0$ membrane, for Cd removal in the dead-end filtration process is depicted in Figure 9. According to the result, $\mathrm{MnO}_{2} / \mathrm{PES}-2.0$ membrane was capable of maintaining the $\mathrm{Cd}$ concentration below the maximum contamination level (MCL) of $10 \mathrm{ppb}$ as stated by World Health Organization (WHO) for approximately $4000 \mathrm{~cm}^{3}$ of permeate.

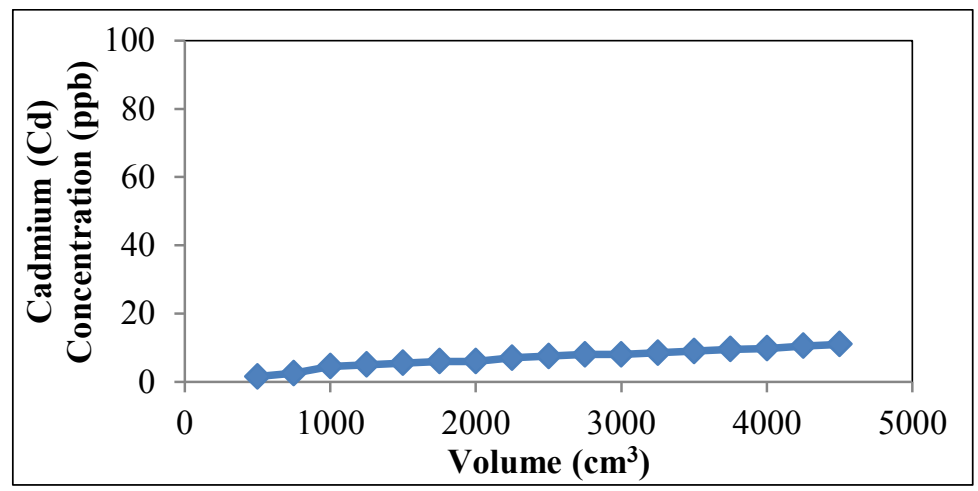

Figure 9. Adsorption of $\mathrm{Cd}$ from aqueous solution using $\mathrm{MnO}_{2} / \mathrm{PES}-2.0$ membrane (Operating conditions: initial $\mathrm{Cd}$ concentration $=100 \mathrm{ppb}, \mathrm{pH}=9$, temperature $=25^{\circ} \mathrm{C}$, pressure $=5 \mathrm{bar}$ )

\section{Conclusion}

In this study, the $\mathrm{MnO}_{2} / \mathrm{PES}$ mixed matrix membranes with different $\mathrm{MnO}_{2}$ additives were successfully fabricated in laboratory scale. The fabricated membrane was characterized to understand the effect of the additives on the membrane morphology. The addition of $\mathrm{MnO}_{2}$ in the membrane showed the increment of the surface roughness and better porosity. The $\mathrm{MnO}_{2} / \mathrm{PES}$ membranes were found to have the highest $\mathrm{Cd}$ removal efficiency between $\mathrm{pH} 9$ and 11 attributed to the electrostatic attraction between the positively charge $\mathrm{Cd}^{2+}$ ions and the negative charged binding 
sites of the functional group which lead to the possible application of $\mathrm{Cd}$ removal at broad $\mathrm{pH}$ range from $\mathrm{pH} 4$ to 11. The filtration results showed that the $\mathrm{MnO}_{2} / \mathrm{PES}-2.0$ membrane was capable of producing permeate of good quality with $\mathrm{Cd}$ concentration below $10 \mathrm{ppb}$ (the MCL set by WHO). This proved that the $\mathrm{MnO}_{2} / \mathrm{PES}-2.0$ membrane was very effective in removing $\mathrm{Cd}$ from aqueous solutions. In summary, the $\mathrm{PES} / \mathrm{MnO}_{2}-2.0$ membrane shows a great potential to be applied $\mathrm{Cd}$ removal from various wastewater treatment industry.

\section{References}

1. Mehdi, G. and Hamid, R. M. (2015). Enhancing performance of hybrid liquid membrane process supported by porous anionic exchange membranes for removal of cadmium from wastewater. Chemical Engineering Journal, 264(1): $241-250$.

2. Tingting, D., Liangrong, Y., Menghao, Z., Zhini, L., Xitong, S., Jiemiao, Y. and Huizhou L. (2015). Removal of cadmium (II) from wastewater with gas-assisted magnetic separation. Chemical Engineering Journal, 280(1): $426-432$.

3. Yilmaz, Y. (2016). Removal of heavy metals in wastewater by using zeolite nano-particles impregnated polysulfonemembranes. Journal of Hazardous Materials, 309(1): 53 - 64.

4. Chong, K. C., Lai, S. O., Lee, K. M., Lau, W. J., Ismail, A. F. and Ooi, B. S. (2014). Characteristic and performance of polyvinylidene fluoride membranes blended with different polymeric additives in direct contact membrane distillation. Desalination and Water Treatment, 2014 (1): 1 - 9.

5. Mocha, N. M., Lau, W. J., Ng, B. C., Ismail, A. F. and Veerasamy, D. (2015). Preparation and characterization of PVDF membranes incorporated with different additives for dyeing solution treatment using membrane distillation. Desalination and Water Treatment, 56(1): 1999 - 2012.

6. Bourawi, M., Ding, Z. and Khayet, M. (2006). A framework for better understanding membrane distillation process. Journal of Membrane Science, 285(1): 4 - 29.

7. Subramanian, V., Zhu, H. and Wei, B. (2008). Alcohol-assisted room temperature synthesis of different nanostructured manganese oxides and their pseudocapacitance properties in neutral electrolyte. Chemical Physics Letters, 453(4-6): $242-249$.

8. Ahmad, A. L., Ideris, N., Ooi, B. S., Low S. C. and Ismail, A. (2012). Synthesis of polyvinlidene fluoride (PVDF) membranes for protein binding: Effect of casting thickness. Journal of Applied Polymer Science, 128(5): $3438-3445$.

9. Chong, K .C., Lai, S. O., Lau, W. J. and Ooi, B.S. (2014). Preparation, characterization and performance of polyvinylidene fluoride membrane for sodium chloride rejection in direct contact membrane distillation. Materials Research Innovation, 18(S6): 359 - 363.

10. Jamshidi Gohari, R., Halakoo, E., Nazri, N., Lau, W. J, Matsuura, T. and Ismail, A. (2014). Improving performance and antifouling capability of PES UF membranes via blending with highly hydrophilic hydrous manganese dioxide nanoparticles. Desalination, 335(1): 87 - 95.

11. Al-Homaidan A., Jamila A. A., Al-Hazzani A. A., Al-Ghanayem A., Alabbad A. F. (2015). Adsorptive removal of cadmium ions by Spirulina platensis dry biomass. Saudi Journal of Biological Sciences, 22: $795-800$.

12. Adhiya J., Xiaohua C., Richard T. S., Samuel J. T. (2002). Binding of aqueous cadmium by the lyophilized biomass of Chlamydomonas reinhardtii. Colloids and Surfaces, 210: 1-11. 